Received: July 20, 2017

Revision received: May 2, 2018

\title{
Construction and Application of Undergraduate Professional Practice Teaching System in Water Conservancy
}

\author{
Shikui Liang ${ }^{1}$ \\ North China University of Water Resources and \\ Electric Power; \\ Collaborative Innovation Center of Water \\ Resources Efficient Utilization and Protection \\ Engineering
}

\author{
Xianqi Zhang ${ }^{2}$ \\ North China University of Water Resources and \\ Electric Power; \\ Collaborative Innovation Center of Water \\ Resources Efficient Utilization and Protection \\ Engineering
}

\begin{abstract}
Undergraduate Professional Practice Teaching System of Water Conservancy has typical profession characteristics. Combine with the undergraduate professional talent training plan of North China University of Water Resources and Electric Power, Hohai University and Wuhan University, analysis the teaching practice system from the aspects of training goal and course system setting, put forward in the new era of undergraduate professional practice teaching system in the construction of water conservancy, should strengthen the construction of practice base and teaching staff, innovation of teaching management.
\end{abstract}

\section{Keywords}

Higher Education of Water Conservancy • Undergraduate Program • Practice Teaching • Teaching System

\footnotetext{
*The author wishes to thank the National Natural Science Foundation of China for contract 51609087, Key project of scientific research in Colleges and Universities of Henan Province for contract 17A570004, Collaborative Innovation Center of Water Resources Efficient Utilization and Protection Engineering, Henan Province, and 2017 Famous Teacher Training Program of NCWU, under which the present work was possible.

${ }^{1}$ North China University of Water Resources and Electric Power, Zhengzhou 450045, China; Collaborative Innovation Center of Water Resources Efficient Utilization and Protection Engineering, Zhengzhou 450046, China. Email: 30696792@ qq.com ${ }^{2}$ Correspondence to: Xianqi Zhang, North China University of Water Resources and Electric Power, Zhengzhou 450045, China; Collaborative Innovation Center of Water Resources Efficient Utilization and Protection Engineering, Zhengzhou 450046, China. Email: zxqi@ 163.com
}

Citation: Liang, S. K., Zhang, X. Q. (2018). Construction and Application of Undergraduate Professional Practice Teaching System in Water Conservancy. Educational Sciences: Theory \& Practice, 18(5), 1922-1931. http://dx.doi.org/10.12738/estp.2018.5.091 
Water conservancy is the basic industry of national economic and social development. It has typical industry characteristics. The water conservancy work covers a wide range, systematic and comprehensive. The complexity and change of water problems make it needs higher requirements of comprehensive and innovative for professional talents (Zuo, 2011). Water conservancy higher education mainly includes specialties, undergraduate and postgraduate education, they are the main way to train water professionals. Among them, undergraduate education plays an important role in the cultivation of professional talents. In the "Undergraduate Professional Catalogue of General Colleges and Universities" promulgated in 2012, the water conservancy majors include water conservancy and hydropower engineering, hydrology and water resources engineering, port waterway and coastal engineering. In addition, agricultural water conservancy projects are agricultural engineering, because it has been involved in water conservancy activities and have been set up in many water conservancy institutions in China. In recent years, water conservancy projects and higher education have flourished, and the requirements for the training of water conservancy talents have also been continuously improved. Colleges and universities are also actively carrying out reforms in education and teaching systems to meet the needs of professional development for professional development.

Undergraduate education can be divided into three types which are science education, engineering education and technology education according to the social talent types and the social activities of cognition and alteration the world (Xia \& Liu, 2007). Practice teaching is an important part of higher education teaching system. Based on professional knowledge education, students' comprehensive training in practical ability, professional quality and innovative ability plays an important role in the cultivation of engineering talents such as water conservancy (Zheng et al., 2015). In China's higher education, the specific content of practical teaching is often determined at the beginning of talent training. Therefore, the reform or development of the practical teaching system, the important content is to optimize the curriculum structure, and establish a reasonable practical curriculum in combination with the training program. Start with professional training objectives, and continuously integrate and optimize practical teaching content in light of changes in talent needs. The development concept of water conservancy industry is constantly improving with the development of economy and society, and the level of water conservancy construction is also rapidly increasing. The demand for talents in modern water conservancy makes it necessary for colleges and universities to adjust the orientation and training objectives of talent cultivation and innovate talent training mode in a timely manner. The principle-optimized curriculum system of "Basic Foundation, Heavy Crossing, Quality, and Practice" has become the consensus of water conservancy higher education (China Water Education Association, 2009). Keeping up with the development trend of the industry and continuously promoting the reform of the practical teaching system of water conservancy undergraduate courses is of great significance to the training of water conservancy professionals.

\section{Current situation of practice teaching system for undergraduate of water conservancy}

The teaching system refers to various forms of education and teaching organization formed in order to achieve certain educational and teaching purposes and achieve certain functions of education and teaching (Huang, 2014). The teaching system includes curriculum setting, curriculum arrangement and teaching 
evaluation. Practical teaching is an important part of the teaching system. It runs through the whole process of the teaching system. The practical teaching system is the overall design and reasonable arrangement of the various elements in the practical teaching link. Corresponding to theoretical teaching, its contents include experiments, internships, curriculum design, etc (Li, 2007). China's water conservancy institutions have always attached importance to practical teaching in terms of personnel training. There are relatively many practical courses and teaching links. However, due to various factors, practical teaching has found many practical problems.

\section{There is a deviation in the practice teaching concept}

The educational concept of "heavy theory and light practice" has long existed in educational practice. The water conservancy higher education in the new situation recognizes the important role of practical teaching, and then emphasizes "engineering education", that is, focusing on a unified compulsory course and attaching importance to practical courses and teaching. "Engineering education" has effectively improved the practical ability of talents, but neglected the general education of students, which has limited the ability to innovate talents. The cultivation of water conservancy talents under the background of popular higher education needs to change the traditional professional education into quality education, and establish a concept of talent cultivation that integrates theoretical knowledge, practical ability and innovative ability.

\section{The structure of the practical teaching course is not very reasonable}

The content system of practical teaching includes experimental internships, professional experiments, production internships and social practice. The teaching system is a scientific system, which needs to be carried out in accordance with the teaching rules. The corresponding opening time and development method of the practical curriculum must be reasonably set, including the pre-requisite courses and theoretical foundations. At present, in the practical teaching system of colleges and universities, the experimental aspects are mostly verification experiments attached to the theoretical curriculum. There are few comprehensive and innovative experiments, and students' enthusiasm for learning, innovation and lack of ability. In the practice or implementation of practical practice teaching, there is a great randomness, the internship time is uncertain, the content of the internship is unreasonable, and the process of development is not standardized.

\section{The effect of practical teaching is difficult to evaluate}

The conditions of the practice base have an important impact on the smooth development of the internship teaching. Affected by many factors, some colleges and universities have insufficient protection for the construction of internship bases, and the shortage of internship funds is widespread, making it difficult for normal off-campus internships to be carried out normally. Most of the off-campus internships are in the form. Visiting and listening to lectures have become the main method. It is difficult for students to get in touch with 
the first-line exercise learning opportunities, and the internship effect is not guaranteed (Sun, 2014). The assessment of student practice scores is usually based on simple assessments such as student attendance, reports, etc. The lack of reasonable basis for the evaluation of practical teaching results has many adverse effects on the subsequent practical teaching work.

\section{Analysis on the reform of practical teaching system for water conservancy Majors}

Water conservancy higher education always attaches great importance to the construction of practical teaching system. This paper selects the three universities of North China University of Water Resources and Hydropower, Hohai University and Wuhan University as the representative, taking the undergraduate training program of hydrology and water resources in the undergraduate course of water conservancy as an example. Conduct a comparative analysis of professional practice teaching systems.

\section{Practice requirements in teaching objectives}

The teaching goal is a direct reflection of the teaching philosophy. Affected by the educational objectives, characteristics of the disciplines and development goals of various institutions of higher learning, the training objectives set by the same profession also have their own characteristics. Taking the training objectives of the undergraduate majors of hydrology and water resources engineering in three colleges and universities as an example, all three universities pointed out that "cultivating high-quality applied talents that meet the needs of the economy and society and requiring students to have practical ability and innovative spirit" while essential basic theoretical knowledge, both Hohai University and North China University of Water Resources and Hydropower emphasize the learning of "natural sciences and humanities". In terms of training characteristics, Wuhan University puts forward that "theoretical methods and techniques should be applied equally". Hohai University requires "the basic ability to analyze and solve practical problems, carry out scientific research and engage in management work". North China University of Water Resources and Hydropower highlights "professional basic knowledge and basics". Skills, analysis and solving practical problems, carrying out scientific research and basic skills in organizational management.

It can be seen from the training objectives of the professional talents of the three universities that the cultivation of applied talents with solid theoretical and practical skills has become the consensus for the development of water conservancy higher education. At the same time, colleges and universities have also combined their own advantages and development orientation, and put forward the talent training objectives with distinctive characteristics. This concept and practice are worthy of promotion and reference.

\section{Practice curriculum}

The curriculum is the foundation of professional teaching. In the training program, the curriculum is also called the guiding teaching plan, which is the basic basis for professional teaching. In response to the practical teaching curriculum of hydrology and water resources engineering, Wuhan University has listed nineteen 
practical teaching projects related to experiments, internships and curriculum design in the form of "centralized practice teaching". In the "Practical Teaching Instructional Program", Hohai University lists a total of twentyfour teaching practice courses including the practice of quality courses, and clearly stipulates the course name, credits and the semester of the course, and provides practice. The teaching courses is compulsory courses. In addition, the credits for quality development are not less than ten credits in the graduation conditions. In the professional "practical teaching link", North China University of Water Resources and Hydropower listed sixteen teaching practice courses. The number of practical courses is relatively small compared with the other two universities, but the number of relevant courses and some internships are more.

Comparing and analyzing the practical teaching curriculum system of the three universities, we can see that the practical curriculum includes several aspects: First, the practice of trainee, according to the characteristics of professional teaching, through the understanding of internships, course trainees, professional inspection methods, increase and expand the professionalism of students Recognition, such as physical geography internships, meteorological internships, etc.; second, experimental teaching, for some professional and technical courses, through demonstration, verification or design experiments, to improve the effectiveness of theoretical teaching, such as physical experiments, hydraulic experiments; Third, the curriculum design, based on the basic theories learned, formulate relevant issues, cultivate knowledge application ability, application requirements, such as hydrological forecasting, water conservancy calculation curriculum design, etc.; Fourth, social practice, through professional related investigation, social practice, etc. To cultivate students' practical ability and improve the overall quality of students; the fifth is the graduation internship and thesis writing, and cultivate the ability to comprehensively apply professional knowledge and skills to solve practical problems.

On the whole, the practical teaching curriculum of the three universities includes general courses, professional courses, professional courses and practical teaching courses. The specific practical contents of several aspects are intertwined with the deepening and development of the teaching process, thus forming a system. A complete practical teaching system is an important teaching link for cultivating students' comprehensive abilities.

\section{Practice teaching effect and evaluation}

The professional training programs of the three universities have determined the hours and credits of the practical teaching courses and the minimum credit requirements that should be achieved throughout the academic period. However, there is no clear basis for how to carry out the effect confirmation and evaluation for each specific practice. Combining the understanding of the teaching development of the three universities, for some experiments and graduation thesis, the scores of the results of the practice and design can be assessed or the scores are answered. Most of the practical internships are evaluated according to the grades of the text reports, or the internships. The unit gives an overall evaluation based on the overall performance of the students, but they cannot objectively reflect the effect of the internship. Like most colleges and universities, there are problems in the practice of teaching that are difficult to evaluate, which often affects students' practical enthusiasm and exacerbates the arbitrariness of practical teaching. 


\section{Principles for constructing a practical teaching system}

Practical teaching is an important part of the higher education teaching system, an effective form to stimulate students' innovative ability, and an important way to cultivate students' innovative spirit and practical ability. In order to cultivate innovative talents that meet the needs of the society, colleges and universities must integrate the professional innovation and practical ability from the perspective of optimizing the professional training process, and integrate the students' innovative consciousness and practical ability into the whole practice teaching process. Clear and closely connected, consisting of production labor, understanding of internships, curriculum experiments, curriculum design, teaching internships, scientific research training, graduation internships and graduation thesis (design), gradually inspiring and developing students' creative thinking and cultivating students' innovative consciousness A relatively completely new practice teaching system with practical ability.

Practical teaching is a comprehensive training link to train students' practical knowledge, practical ability and comprehensive quality. As a part of university education, practical teaching must strengthen the combination with theoretical teaching, adapt to the requirements of the times and social development, and conduct in-depth research on educational thoughts, educational concepts, educational content, teaching methods, educational management and even educational models. Innovate. It is the first step in cultivating innovative talents. First of all, from the ideological changes people's understanding of practical teaching in the traditional teaching system; Secondly, focus on the practice of teaching reform, including it into the school's overall teaching reform, fully highlighting the important position of practical teaching in the entire teaching work. The generalized practice teaching exists in the whole teaching process, with wide connotation and various forms, including classroom practice teaching, campus practice teaching and social practice teaching. Practical teaching should focus on close integration with scientific research. Through a series of scientific research activities, students are taught to explore ways of knowledge, so that students' awareness of innovation is gradually enhanced and their creative ability is continuously improved. Practical teaching should make full use of the school's own resource advantages, and design practical teaching programs for different subjects and different students, so that all kinds of students can get good training. In practice teaching, it is necessary to closely design and integrate the teaching objectives in the design of each teaching link, so that the practical teaching can be three-dimensional.

The principles for constructing a practical teaching system should include the following aspects:

(1) Objectives. The construction of practical teaching system must focus on the training standards of college personnel and the training objectives of professional talents. It is necessary to start from the requirements of professional knowledge and professional skills, and put forward the specific objectives of the cultivation of practical ability in this profession, and take it as the goal of constructing practical teaching system.

(2) Systematic. According to the law of higher education and the characteristics of the training of various professionals, we should proceed from the requirements of the comprehensive development of human quality 
and ability, and follow the status, role and internal relationship of each practical teaching link, and use the systematic scientific method to construct practice. The teaching system is in line with the reform of the personnel training program and the curriculum system, focusing on the mutual penetration of practical teaching and theoretical teaching, so that all links within the system are connected, coordinated and unified, and have continuity throughout the entire process of university education.

(3) Hierarchy. The improvement of practical ability is a gradual process, so the practical teaching in the university training plan should be gradually deepened in stages and levels.

(4) Normative. The construction of the practical teaching system must be carried out in parallel with the formulation of the talent training plan, incorporating the perfect operation mechanism of the talent training plan, and standardizing the teaching content, form and corresponding assessment standards and requirements of each practical teaching link.

(5) Practical. The construction of the practical teaching system must be based on a certain educational theory, and it is very scientific and practical, and easy to operate.

\section{Discussion on the development of practical teaching system for water conservancy Majors}

In the new era, the professional training system for water conservancy disciplines should reflect the scientific concept of quality training of talents. It should be multi-level, multi-type, multi-faceted and multi-form, and adapt to the needs of the diversity of professionals in water science disciplines. The goal is to cultivate highquality talents with "thick foundation, broad professionalism, strong quality, emphasis on practice, and innovation".

As an important part of the higher education teaching system, practical teaching plays an irreplaceable role in the cultivation of students' innovative spirit and practical ability. In the context of popularized higher education, it is necessary to optimize the professional teaching system. In the practice teaching process, while formulating scientific and rational training plans, it is necessary to constantly update the practical teaching concepts, improve the practical teaching conditions, optimize the structure of the teaching staff, innovative teaching management mode, etc., to provide a guarantee for the smooth development of practical teaching.

\section{Constantly updating the concept of practical teaching}

Talent cultivation is a long-term process. The goal of professional talent training also has certain characteristics of the times. The practical teaching system and its contents can keep up with the development trend of the industry, and continuously improve and adjust in time. At present, education and teaching reform is flourishing in higher education and college teaching. To reform the practical teaching concept, it needs to be forward-looking in terms of industry development and talent training needs. In the way of thinking, establish 
the concept of "big practice" and carry out various teaching. Forms such as classroom practice, campus practice, social practice, etc. In the practical content, based on routine experiments, visits, internships, encourage innovative experiments, innovative design, etc., on the basis of enhancing students' practical ability, inspire their innovative consciousness and innovative ability.

\section{Improve the conditions of practical teaching}

At present, the practical teaching curriculum is relatively reasonable. In the implementation process, the biggest problem is the lack of practice teaching base construction. The practice teaching base mainly includes on-campus laboratories and off-campus practice bases. At present, based on the country's increasing investment in higher education, the laboratory construction of colleges and universities is developing rapidly. The main problem is that it needs to meet the needs of teaching while matching the construction of disciplines and curriculum construction, and try to improve the efficiency of laboratory use. The construction of off-campus internship bases can be constructed in a combination of production, learning and research, which is convenient for long-term and stable cooperation and operation. The "Engineering Excellence Program" and the "Innovative Ability Enhancement Plan for Higher Education Institutions" implemented by the Ministry of Education all propose talent training. In terms of strengthening the cooperation between universities and enterprises, the North China University of Water Resources and Hydropower University has been supported by two programs and has carried out the construction of a teaching practice base. At the same time, it is necessary to pay attention to the cultivation of practical teaching teams, optimize the overall structure of the teaching staff of practical teaching, and improve the level of innovation in teaching practice.

\section{Innovative teaching management mode}

The price system and management system are the key steps in the implementation of practical teaching, and are the guarantee for the realization of teaching objectives and content. Teaching management refers to a series of activities such as planning, organizing, coordinating and evaluating the entire teaching process. In the current water conservancy undergraduate practice teaching process, it mainly involves the revision of the teaching plan, the management of the practice link, and the evaluation of practical teaching. Under the current conditions, the revision of college teaching plans often lags behind the development of disciplines. While ensuring the science and system of the teaching system, there should be some flexibility to quickly adapt to the knowledge and ability of talents in the development of the industry. In the aspect of practice link management, we should break through a single management mode. In terms of practical teaching content and teaching methods, including practical teaching evaluation methods, we must be brave in reform and innovation. For example, in the graduation design process, students are encouraged to combine production practice with production units. Write a thesis, the results of the combination of on-campus and off-campus methods in a comprehensive way to assess. 


\section{Conclusion}

The construction of the practical teaching system for undergraduate majors in water conservancy is an important guarantee for improving students' practical ability, comprehensive quality and innovation consciousness, and ensuring the quality of professional personnel training. Water conservancy universities should closely combine the development trend of the industry, guide the professional training objectives and direction through advanced education and teaching concepts, scientifically set and continuously optimize the professional practice teaching curriculum, actively explore the practical teaching innovation management mode, and continuously promote the further development of personnel training and water conservancy industry.

In order to meet the development needs of the water conservancy industry in the new era, water conservancy higher education urgently needs to reform the current teaching mode and content, improve the knowledge and skills and adaptability of college graduates, and fully meet the water conservancy in the quantity, specification, level, type and quality of personnel training. The need for reform and development. In terms of professional structure, it is necessary to adapt to the new ideas of water conservancy development, explore and construct a new teaching system for water conservancy disciplines, and train talents who have mastered the theoretical knowledge of modern water conservancy and sustainable development of water conservancy. In terms of the talent training model, it is necessary to change the single professional education into a compound education, establish a compound training model, cultivate a group of people who know both engineering and social management, understand water resources development and protection, understand water management, urban flood control, high-level, compound talents in urban water supply, engineering construction and management. At the same time, the content and form of water conservancy work in the new era are constantly developing and changing. Therefore, new requirements are put forward for the cultivation of talents in higher education, and more emphasis is placed on cultivating the comprehensive adaptability, practical ability and innovative ability of talents. These new talent training requirements are an important future for the realization of water conservancy reform and development, and also a guarantee for the sustainable development of water conservancy projects.

\section{References}

China Water Education Association. (2009). How can water conservancy universities cultivate talents that meet the needs of modern water conservancy. China Water Resources, (16), 1-4. http://doi.org/10.3969/j.issn.1000-1123.2009.16.002.

Huang, M. (2014). Research on practical teaching and performance evaluation methods for water conservancy and hydropower engineering. China Electric Power Education, (17), 100-102. http://dx.doi.org/10.3969/j.issn.1007-0079.2014.17.048.

Li, G. Y. (2007). Research and practice of teaching applied undergraduate hydraulic engineering economics teaching. Education and Occupation, (36), 111-112. http://dx.doi.org/10.3969/j.issn.10043985.2007.36.048 
Sun, N., Li, H., Liu, D., Liu, Y. C., Xu, G. J. \&Wang, Z. B. (2014). The construction of water conservancy practice teaching implementation plan for innovative talents training. Science and Technology Innovation Guide, (7), 118-119. http://dx.doi.org/10.3969/j.issn.1674-098X.2014.07.084.

Xia, J. G. \& Liu, X. B. (2007). Applied undergraduate education: Background and essence. Higher Education Research, (3), 92-95. http://dx.doi.org/10.3969/j.issn.1001-4233.2007.03.020.

Zheng, Y. Y, Wang, H \& Li, Y. L. (2015). Exploration of practical teaching mode based on cultivation of innovation ability. Education and Occupation, (2), 164-165. http://dx.doi.org/10.3969/j.issn.10043985.2015.02.078.

Zuo, Q. T. (2011). Discussion on the disciplinary system and research framework of water science. South-toNorth Water Transfers and Water Science and Technology, 9(1), 113-117. http://dx.doi.org/10.3724/SP.J.1201.2011.01113. 